\title{
Quaternaire
}

Revue de l'Association française pour l'étude du

Quaternaire

vol. 28/2 | 2017

Volume 28 Numéro 2

\section{Recent advances on the dynamical representation and our understanding of the warmer-than-present last interglacial climate}

Reconstitution spatio-temporelle et compréhension du climat chaud du dernier interglaciaire - un point sur les avancées récentes

Émilie Capron, Aline Govin and Emma J. Stone

\section{revues.org}

Electronic version

URL: http://quaternaire.revues.org/8029

DOI: 10.4000/quaternaire.8029

ISSN: 1965-0795
Publisher

Association française pour l'étude du quaternaire

Printed version

Date of publication: 29 May 2017

Number of pages: 185-193

ISSN: 1142-2904

\section{Electronic reference}

Émilie Capron, Aline Govin and Emma J. Stone, « Recent advances on the dynamical representation and our understanding of the warmer-than-present last interglacial climate », Quaternaire [Online], vol. 28/2 | 2017, Online since 01 June 2017, connection on 20 July 2017. URL : http:// quaternaire.revues.org/8029; DOI : 10.4000/quaternaire.8029 


\title{
RECENT ADVANCES ON THE DYNAMICAL REPRESENTATION AND OUR UNDERSTANDING OF THE WARMER-THAN-PRESENT LAST INTERGLACIAL CLIMATE
}

\author{
Emilie CAPRON ${ }^{1,2}$, Aline GOVIN ${ }^{3} \&$ Emma J. STONE
}

\begin{abstract}
The Last Interglacial (LIG, 129-116 thousand years Before Present, hereafter ka) represents an ideal case study to understand the climate mechanisms at play under a warmer-than-present climate. However a spatio-temporal representation of the LIG climatic changes remains difficult to obtain, mainly because aligning paleoclimatic records from various archives (i.e. polar ice cores, marine sediments, speleothems) from around the globe is challenging. Here we summarize recent studies that highlight how the coupling of a synthesis of surface air and sea temperature records (above polar ice sheets and from the North Atlantic and Southern Ocean respectively) associated with harmonized chronologies and of appropriate climate model experiments improved our spatio-temporal representation of the LIG high-latitude climate evolution, and our understanding of the mechanisms at play, especially at the beginning of the LIG. In particular, we describe commonly-used record alignment strategies for marine sediment cores and we show that age discrepancies larger than $4 \mathrm{ka}$ can exist between the timescales inferred from the different approaches. Providing harmonized chronologies when comparing multiple records is thus essential and we propose a new high latitude LIG data synthesis based on coherent record time scales together with associated time slices at 130,125,120 and $115 \mathrm{ka}$ of surface temperature anomalies relative to present-day. The results provide the first robust evidence for asynchronous surface temperature evolutions at the LIG onset across the world and also enable one to identify important missing processes in state-of-the-art model climate simulations to reproduce the early LIG climate evolution. Our integrated model-data approach shows that a freshwater input into the North Atlantic (due to the Northern Hemisphere ice sheet early melting) needs to be accounted for in addition to the orbital and greenhouse gas concentration forcing in climate simulations, to explain the evolution of the early LIG climate.
\end{abstract}

Key words: last interglacial period, chronology, high latitude surface temperature synthesis, climate model simulations.

\section{RÉSUMÉ}

RECONSTITUTION SPATIO-TEMPORELLE ET COMPRÉHENSION DU CLIMAT CHAUD DU DERNIER INTERGLACIAIRE - UN POINT SUR LES AVANCÉES RÉCENTES

La dernière période interglaciaire (LIG, 129-116 milliers d'années avant aujourd'hui, ka) représente un cas d'étude privilégié pour comprendre les mécanismes climatiques en jeu dans le contexte d'un climat plus chaud que l'actuel. Cependant, obtenir une représentation à la fois spatiale et temporelle des changements climatiques au cours du LIG reste compliqué. Ceci est principalement dû à la difficulté à construire des modèles d'âge harmonisés pour des enregistrements paléoclimatiques provenant d'archives différentes (par exemple, carottes de glace, sédiments marins, spéleothèmes) et géographiquement dispersées. Dans ce manuscrit, nous résumons trois études récentes qui illustrent qu'en couplant une nouvelle synthèse de données de température de l'air au-dessus du Groenland et de l'Antarctique et des eaux de surface (dans l'Atlantique nord et l'océan Austral) basée sur un cadre chronologique cohérent, avec des simulations numériques appropriées, il est possible d'avancer notre connaissance sur les changements climatiques qui se sont produits pendant le LIG, et en particulier sur les mécanismes en jeu aux hautes latitudes au début du LIG. Nous décrivons d'abord les stratégies d'alignement communément utilisées pour définir les modèles d'âges des enregistrements sédimentaires marins couvrant le LIG. Nous montrons que des désaccords de plus de 4000 ans peuvent être observés entre les modèles d'âges obtenus à partir des différentes approches. Il est donc essentiel de proposer des chronologies harmonisées lorsque l'on compare de multiples enregistrements paléoclimatiques sur le LIG. C'est pourquoi, nous avons établi une nouvelle synthèse des données de température de surface associée à un cadre chronologique cohérent. Cette nouvelle synthèse pour le LIG se focalise sur les régions des hautes latitudes. Nous proposons aussi quatre cartes représentant des instantanés à $130,125,120$ et 115 ka des anomalies de température de surface relatives à l'actuel. Nos résultats mettent en évidence de manière robuste qu'à l'échelle globale, les changements de température ne se sont pas tous produits au même moment au début du LIG. En comparant la carte d'anomalie de température à 130 ka avec des températures de surface simulées pour le même intervalle de temps par un modèle de circulation générale, nous montrons que ce dernier n'est pas en mesure de reproduire les changements climatiques observés dans les enregistrements paléoclimatiques lorsqu'il est forcé uniquement par la configuration orbitale de la Terre et les concentrations atmosphériques en gaz à effet de serre à $130 \mathrm{ka}$. En particulier, notre approche combinant les anomalies de température reconstruites à $130 \mathrm{ka}$ avec de nouveaux résultats de modélisation suggère que pour expliquer l'évolution du climat au début du LIG, il est nécessaire de prendre en compte un forçage additionnel, celui lié à l'apport d'eau douce dans l'Océan atlantique nord associé à la fonte des calottes de glace de l'hémisphère nord.

Mots-clés: le dernier interglaciaire, échelle d'âge, synthèse de données de température de surface pour les régions de haute latitude, simulations climatiques

\footnotetext{
${ }^{1}$ Centre for Ice and Climate, University of Copenhagen, Juliane Maries Vej 30, DK-2100, COPENHAGUEN. Email: capron@nbi.ku.dk

${ }^{2}$ British Antarctic Survey, High Cross Madingley Road, GB-CB3 0ET, CAMBRIDGE.

${ }^{3}$ IPSL/LSCE, Laboratoire des Sciences du Climat et de l'Environnement (CEA-CNRS-UVSQ), Université Paris-Saclay,

FR-91198, GIF-SUR-YVETTE. Courriel: aline.govin@1sce.ipsl.fr

${ }^{4}$ BRIDGE, School of Geographical Sciences, University of Bristol, University Road, GB- BS8 1SS, BRISTOL.

Email: emma.j.stone@bristol.ac.uk
} 


\section{1 - INTRODUCTION}

The Last Interglacial (LIG, 129-116 thousand years Before Present, hereafter ka) is commonly used as a test bed to investigate the response of the Earth System to global warming. Indeed, this period is characterized by a global climate a few degrees warmer than present-day, in particular in high latitudes (e.g. Capron et al., 2014), and a global mean sea level 6 to $9 \mathrm{~m}$ above present due to reduced Antarctic and Greenland ice sheets (Dutton et al., 2015) (fig. 1). The warmer-than-present LIG climate derives from high boreal summer insolation values, and not from enhanced greenhouse gas concentrations, which are relatively similar to pre-industrial values (Loulergue $e t$ al., 2008; Lüthi et al., 2008; fig. 1). However, the high-latitude warming reconstructed for the LIG may be reached before 2100 (Otto-Bliesner et al., 2013), making this time period at the forefront of paleoclimatic investigations.

A dynamical representation of the LIG climate evolution is indispensable for two main reasons: (1) to determine the climate dynamics and feedbacks at play during a warmer-than-present climate, and (2) to evaluate, through robust model-data comparisons, the capability of General Circulation Models (GCM), which are used for future climate projections, to reproduce the spatiotemporal evolution of the LIG climate (e.g. Lunt et al., 2013; Bakker \& Renssen, 2014). However, providing a climatic sequence of events across the LIG at a global scale is currently highly challenging, mostly because the comparison of paleoclimatic records from different types of archives and from different parts of the world is strongly limited by chronological issues.

Here, we synthetize recent published efforts on archive's chronologies and model-data comparisons that improve our spatio-temporal representation of climatic patterns and changes, and our understanding of the mechanisms at play in high latitude regions during the LIG. In section 2, we draw the reader's attention to the complexities of chronologies in climatic archives (Govin et al., 2015). We use one example to illustrate how different chronological approaches can lead to large age discrepancies between the resulting timescales, and thus to highlight the importance of harmonizing chronologies in paleo-studies comparing multiple records. In section 3 , we present a new data synthesis for the high-latitude regions which provides robust evidence for asynchronous LIG surface temperature evolutions across the world (Capron et al., 2014). In section 4, we use model-data comparisons at $130 \mathrm{ka}$ to provide new insights on the climatic mechanisms that shaped the inter-hemispheric temperature asynchrony observed during the early LIG (Capron et al., 2014; Stone et al., 2016).

\section{2 - CHRONOLOGICAL LIMITATIONS DURING THE LIG: EXAMPLE OF CLIMATIC ALIGNMENTS IN MARINE SEDIMENTS}

Because of an overall lack of absolute age constraints, it is often necessary to use indirect approaches to infer



Fig. 1: Forcing and climatic records across the 110-140 ka time interval.

The LIG time interval is indicated by the black vertical dotted lines and horizontal arrow between 129 and 116 ka following the definition based on the eustatic sea level (Masson-Delmotte et al., 2013). Records are displayed in panels a), b), c), d) and e) as anomalies relative to the average value of the last 1000 years. a) $21^{\text {st }}$ June insolation across latitudes; b) atmospheric $\mathrm{CO}_{2}$ concentration (Lüthi et al., 2008); c) atmospheric $\mathrm{CH}_{4}$ concentration (Loulergue et al., 2008); d) Antarctic EDC annual surface air temperature reconstruction (Masson-Delmotte et al., 2011); e) Greenland ice $\delta^{18} \mathrm{O}$ : from NEEM ice core (NEEM community members 2013) in dark grey and from NGRIP ice core (NorthGRIP community members 2004) in black. Note that NEEM ice $\delta^{18} \mathrm{O}$ is shifted by $+2 \% ; \mathrm{f}$ ) maximum global mean sea level (GMSL) relative to present-day, uncertainties remain both in the amplitude ( 6 to $9 \mathrm{~m}$; indicated by the shading) and in the exact timing of the LIG GMSL peak. However, most studies point toward a late LIG GMSL peak occurring between 119 and $122 \mathrm{ka}$ (see Dutton et al., 2015 for a review). Records on panels b) to e) are displayed on the AICC2012 chronology (Bazin et al., 2012; Veres et al., 2012; Capron et al., 2014). Fig. 1 : Forçages et enregistrements climatiques entre 110 et140 ka. Le LIG recouvre l'intervalle de temps indiqué par la flèche noire entre 129 et 116 ka selon une définition basée sur les variations du niveau des mers (Masson-Delmotte et al., 2013). Les enregistrements en a), b), c), d) et e) représentent des anomalies relatives la valeur movenne des 1000 dernières années. a) variations latitudinales de l'insolation du 21 juin ; b) concentration en $\mathrm{CO}$, atmosphérique (Lüthi et al., 2008) ; c) concentration en $\mathrm{CH}$ atmosphérique (Loulergue et al., 2008); d) température atmosphérique de surface à Dome C (Masson-Delmotte et al., 2011); e) profil de $\delta^{18} O$ de la glace au Groenland : NEEM en gris foncé (NEEM community members 2013) et NGRIP en noir (NorthGRIP community members 2004). Notez que le $\delta^{18} \mathrm{O}$ de la glace de NEEM est décalé de $+2 \%$; f) niveau des mers global relatif à l'Actuel, des incertitudes demeurent à la fois sur l'amplitude (6 à $9 \mathrm{~m}$; indiqué par le remplissage en pointillés grisés) et sur la date exacte à laquelle le maximum fut atteint. Cependant, la plupart des études suggèrent que le pic s'est produit tard, entre 119 et $122 \mathrm{ka}$ (voir la synthèse publiée par Dutton et al., 2015). Les enregistrements b) à e) sont montrés sur l'échelle d'âge AICC2012 (Bazin et al., 2012, Veres et al., 2012 ; Capron et al., 2014). 
LIG age-depth models. Thus, chronologies of climatic archives are usually based on record alignment strategies, i.e. one record on a depth scale is aligned onto a dated reference record assuming simultaneous regional changes for a given climate variable (e.g. temperature, Govin et al., 2015). As a result, most LIG records are not displayed on chronologies independent from each other and from the assumption of climatic synchronicity. Here we use the case study of core MD95-2042 from the Portuguese margin to compare five different climatic alignment strategies that are commonly used to develop chronologies in marine sediments (fig. 2). A full evaluation of the underlying hypotheses, limitations and age uncertainties associated with these alignment methods can be found in Govin et al., (2015). We briefly summarize them below.

(1) The original age model for core MD95-2042 relies on the assumption that benthic foraminifera $\delta^{18} \mathrm{O}$ variations mostly reflect global ice volume changes, and age markers were based on the alignment of identified high stand sea levels from the benthic foraminifera $\delta^{18} \mathrm{O}$ record with those identified in radiometrically-dated coral terraces (Shackleton et al., 2003). This age model presents severe limitations. First, the radiometric dating of corals at the time was associated with age uncertainties of around
2 ka (Shackleton et al., 2003). More importantly, benthic $\delta^{18} \mathrm{O}$ is strongly affected by seawater $\delta^{18} \mathrm{O}$ and temperature variations (Skinner \& Shackleton, 2006), and cannot be directly related to global sea level changes, in particular on millennial time scales. Last but not least, local coralbased sea level reconstructions were not corrected for glacio-isostatic influences which, since then, have been revealed to be crucial to interpret coral records in term of global eustatic changes (Dutton \& Lambeck, 2012). Reported age uncertainties are thus likely underestimated.

(2) The chronology of marine sediments is often defined by aligning the benthic $\delta^{18} \mathrm{O}$ record onto the benthic $\delta^{18} \mathrm{O}$ reference LR04 stack (Lisiecki \& Raymo, 2005). This alignment strategy assumes that benthic $\delta^{18} \mathrm{O}$ variations are synchronous around the world, and at first order reflect global ice volume changes. However, it has been shown that benthic $\delta^{18} \mathrm{O}$ variations may not occur at the same time and with the same amplitude around the globe, and thus cannot be used as a global marker (e.g. Skinner \& Shackleton, 2005; Waelbroeck et al., 2011). Also, the LR04 stack is associated with large dating errors (i.e. $4 \mathrm{ka}$ ) during the LIG.

(3) The recent improvements of ice core chronologies led to the use of ice core records as targets to define LIG

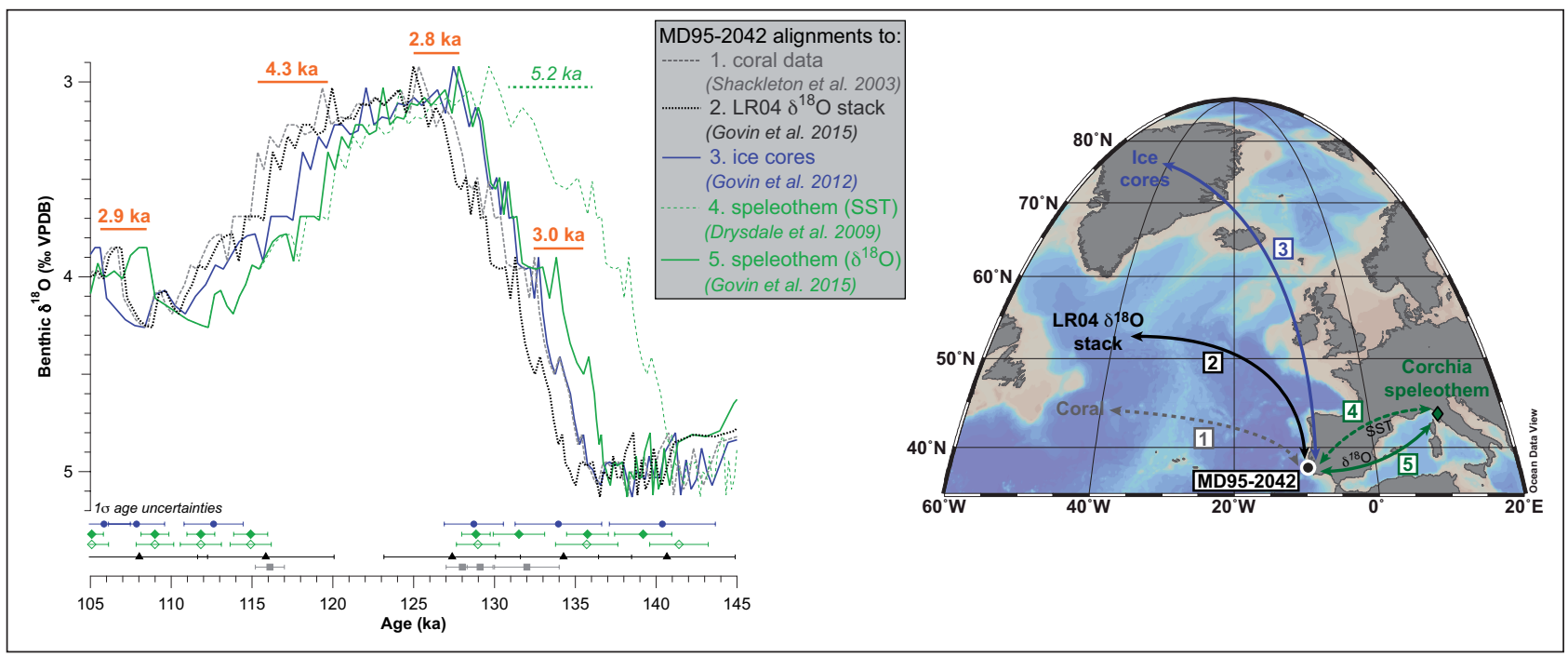

Fig. 2: Benthic foraminiferal $\delta{ }^{18} \mathrm{O}$ of the North Atlantic core MD95-2042 (Shackleton et al., 2003) plotted against ages obtained using five different alignment strategies (figure modified after Govin et al., 2015).

(1) alignment of MD95-2042 benthic $\delta^{18} \mathrm{O}$ to radiometrically-dated coral data (grey dashed line, Shackleton et al., 2003); (2) alignment of MD95-2042 benthic $\delta^{18} \mathrm{O}$ to the LR04 benthic stack (black dotted line, Lisiecki \& Raymo, 2005; Govin et al., 2015); (3) alignment of MD95-2042 planktonic $\delta^{18} \mathrm{O}$ to ice core indicators of Greenland temperature (blue line, Govin et al., 2012); (4) alignment of MD95-2042 alkenone-derived SST to the calcite $\delta^{18} \mathrm{O}$ of the Italian Corchia cave (green dashed line, Drysdale et al., 2009); and (5) alignment of MD95-2042 planktonic $\delta^{18} \mathrm{O}$ to the calcite $\delta^{18} \mathrm{O}$ of the Italian Corchia cave (green plain line, Govin et al., 2015). Tie-points defined for each alignment method (same colour code) are shown with $1 \sigma$ age uncertainties (which include relative matching errors and the absolute dating uncertainty of reference records) at the bottom of the panel. For the alignment method \#1 (original time scale by Shackleton et al., 2003), error bars represent radiometric age errors of coral dating and do not include the uncertainty related to the fact that benthic $\delta^{18} \mathrm{O}$ does not solely reflect sea level changes. Orange horizontal bars show the spread in ages of events between the alignment methods \#1,2,3 and 5. The green horizontal bar indicates the spread in ages during the deglaciation between the alignment methods \#4 and 5 . Fig. 2 : Enregistrement du $\delta^{18} O$ des foraminifères benthiques de la carotte MD95-2042, montré sur cinq modèles d'áge déduits de stratégies d'alignements différentes (figure modifiée d'après Govin et al., 2015).(1) alignement du $\delta^{18} \mathrm{O}$ benthique de la MD95-2042 à des données issues de coraux datés de manière absolue (ligne grise en tirets); (2) alignement du ${ }^{18} \mathrm{O}$ benthique de la MD95-2042 à la courbe composite benthique LR04 (ligne noire en pointillés, Lisiecki \& Raymo 2005 ; Govin et al., 2015) ; (3) alignement du $\delta^{18}$ O planctonique de la MD95-2042 aux traceurs de température du Groenland mesurés dans les carottes de glace (ligne bleue continue, Govin et al., 2012) ; (4) alignement de l'enregistrement de SST (dérivé des alkénones) de la MD95-2042 à l'enregistrement de $\delta^{I 8} O$ de la calcite de la grotte italienne de Corchia (ligne verte en tirets, Drysdale et al., 2009); et (5) alignement $d u \delta^{18} O$ planctonique de la MD95-2042 à l'enregistrement de $\delta^{18} O$ de la calcite de la grotte de Corchia (ligne verte continue, Govin et al., 2015). Les points de calage définis pour chaque méthode d'alignement (même code couleur) sont montrés en bas du graphique, avec l'incertitude associée à lo (qui inclue l'erreur liée à la définition des points de calage et l'erreur de datation absolue associée aux enregistrements de référence. Pour la méthode d'alignement \#1 (échelle d'âge d'origine publiée par Shackleton et al., 2003), les barres d'erreur représentent les erreurs sur les âges absolus déduits des coraux via une méthode de datation radiométrique et n'inclut pas l'incertitude associée avec le fait que les changements de $\delta^{18} O$ benthique ne reflètent pas uniquement des variations du niveau des mers. Les barres horizontales orange montrent la dispersion des âges pour des évènements donnés et qui résulte entre les chronologies déduites des méthodes d'alignements \#1,2,3 and 5. La barre horizontale verte indique la dispersion des âges pour un évènement donné qui résulte entre les chronologies déduites des méthodes d'alignements \#4 et 5. 
age models in high-latitude sediment cores. Govin et al., (2012) proposed a new age model for core MD952042 based on the assumption that glacial-interglacial surface water temperature changes in the subpolar North Atlantic occur in phase with air temperature changes over inland Greenland, which is supported by ${ }^{14} \mathrm{C}$-dated North Atlantic records of the last glacial period (e.g. Bond et al., 1993). The planktonic $G$. bulloides $\delta^{18} \mathrm{O}$ record, which is thought to largely reflect local SST changes at site MD952042 (Shackleton et al., 2000), is thus aligned to ice core indicators of Greenland temperature (Govin et al., 2012).

(4-5) The good dating accuracy of speleothems makes them ideal alignment targets to derive age models in marine sediments in their vicinity (e.g. Bar-Matthews et al., 2003; Drysdale et al., 2009). Drysdale et al., (2009) defined another age model (\#4) to core MD95-2042 by aligning its SST record to calcite $\delta^{18} \mathrm{O}$ from the Italian Corchia cave. To facilitate the comparison with the method \#3, we also aligned MD95-2042 G. bulloides $\delta^{18} \mathrm{O}$ record to Corchia calcite $\delta^{18} \mathrm{O}$ (\#5, Govin et al., 2015). Both methods (\#4-5) rely on two assumptions: (i) variations in the strength of the North Atlantic meridional overturning circulation induce synchronous changes in regional SST, air temperature, evaporation and moisture advection to the Italian peninsula, and therefore Italian rainfall, and (ii) the amount of rainfall reaching Corchia cave is the dominant driver of the calcite $\delta^{18} \mathrm{O}$ signal (Drysdale et al., 2009). However, the uncertainty related to the interpretation of speleothem tracers, and our understanding of factors controlling them, remains difficult to quantify (Govin et al., 2015), and reported age uncertainties are minimal estimates.

The comparison of these multiple chronologies (\#1, 2, 3 , 5; fig. 2) for one marine core shows age discrepancies that can be higher than 4 ka across Termination II, the LIG and the glacial inception. These age offsets are larger than or within the range of $1^{\text {st }}$ age uncertainties (from 0.4 to $4.2 \mathrm{ka}$, depending on the alignment methods; Govin et al., 2015). Therefore, this exercise shows that different chronological methodologies can produce very high age differences across the LIG, and calls for caution when comparing LIG marine records using various alignment targets or different reference time scales.

Also, the comparison of alignment methods \#4 and 5 reveals age differences up to $5 \mathrm{ka}$ during the deglaciation, depending on whether the alkenone-derived SST or planktonic $\delta^{18} \mathrm{O}$ record is aligned to Corchia calcite $\delta^{18} \mathrm{O}$ (fig. 2). Thus, this example shows that, not only the type of alignment method, but also the type of paleo-tracers (e.g. reconstructing SST) used within a same alignment method, can lead to very high age differences (Govin et al., 2015).

Therefore, this case study highlights (i) the importance of reporting precisely the alignment method for a given studied site, (ii) the importance of checking the coherence of age models when integrating multiple records, in particular from different regions, and (iii) the need to systematically estimate relative and absolute chronological uncertainties and integrate them in paleoclimatic investigations (Govin et al., 2015). As further illustration of these issues, we show in the next sections how harmonizing chronologies of records gathered in LIG data syntheses leads to our improved understanding of the LIG climate evolution and related processes.

\section{3 - A NEW LIG CLIMATE DATA SYNTHESIS WITH HARMONIZED CHRONOLOGIES}

Existing LIG surface temperature data syntheses (e.g. Turney \& Jones, 2010; McKay et al., 2011) present two main limitations. First, they use the original chronologies of paleoclimatic records, whose coherence has not been checked, possibly leading to high age discrepancies between records (see section 2). Second, these data syntheses consist of a single time slice focused on the peak of LIG warmth. This approach is problematic, because there are multiple evidences that LIG surface temperatures peaked asynchronously around the globe (e.g. Bauch \& Erlenkeuser, 2008; Govin et al., 2012).

Here we present a new LIG surface temperature data synthesis for high-latitude regions (Capron et al., 2014), the first one with harmonized chronologies. We compiled 5 surface air temperature records above Greenland and Antarctica, and 43 sea surface temperature records from the North Atlantic and the Southern Ocean poleward of $40^{\circ} \mathrm{N}$ and $40^{\circ} \mathrm{S}$ across the LIG. Surface air temperature records are deduced from water stable isotopic profiles of ice cores. Sea surface temperatures (SST) are reconstructed from foraminiferal $\mathrm{Mg} / \mathrm{Ca}$ ratios, alkenone unsaturation ratios, and faunal assemblages in marine sediment cores. The common temporal framework is based on the alignment of SST records to ice core records (Capron et al., 2014) onto the recent Antarctic ice core chronology AICC2012 (Bazin et al., 2013; Veres et al., 2013). The rationales for using this strategy are threefold:

(1) It allows integration of both marine and ice core records.

(2) It better reproduces known high-latitude climate features of the penultimate deglaciation and the LIG than benthic $\delta^{18} \mathrm{O}$ alignments to the LR04 stack (Govin et al., 2015).

(3) AICC2012 is the first integrated ice core timescale over the LIG, based on a multi-site approach including five Greenland and Antarctic ice cores. The numerous new stratigraphic links significantly reduce the absolute dating uncertainty down to $\pm 1.6 \mathrm{ka}(1 \sigma)$ across the LIG (Bazin et al., 2013), making it a particularly wellconstrained reference time scale. Finally, we quantified the surface temperature uncertainties using a Monte-Carlo analysis (i.e. reconstruction of 1000 different age-models per site) that integrates temperature reconstruction errors, and propagates chronological uncertainties (see Capron et $a l$., 2014 for details). These results in a final $2 \sigma$ uncertainty estimate of $\pm 2.6{ }^{\circ} \mathrm{C}$ on average for SST records and $\pm 1.5^{\circ} \mathrm{C}$ for surface air temperature Antarctic records.

We focus now on the four time slices built at $1++30$, 125,120 , and $115 \mathrm{ka}$, for which we calculated temperature anomalies relative to present-day conditions and associated $2 \sigma$ uncertainties over a 2 ka time windows centred on each date (fig. 3; see Capron et al., 2014 for 

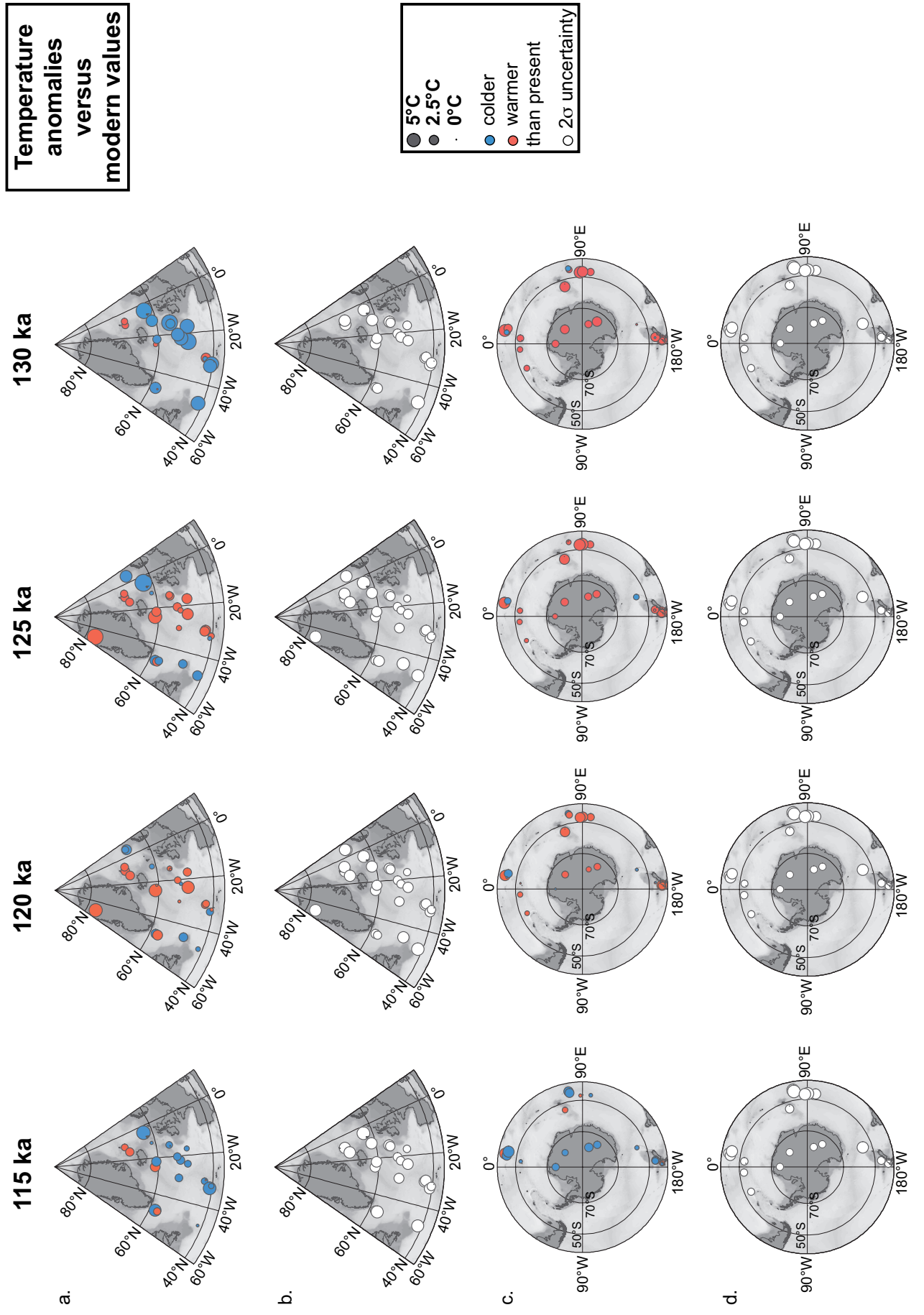

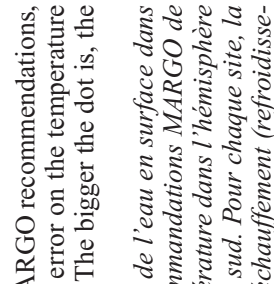

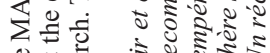

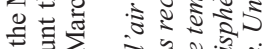

on

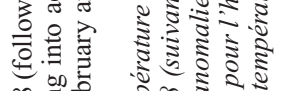

क.



ฮี

ช.ษ

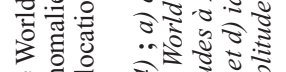

워



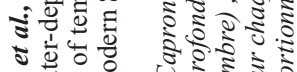

装.

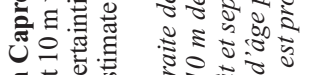

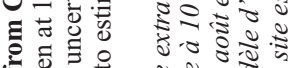



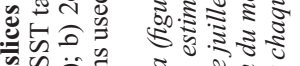

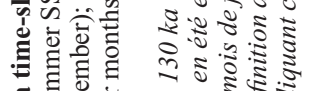

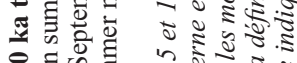



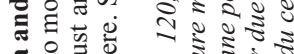

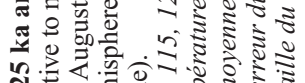

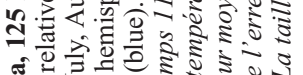

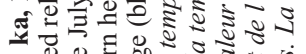

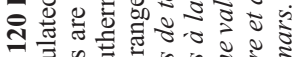

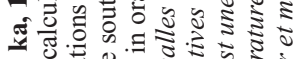



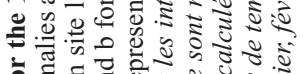

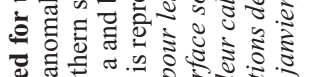

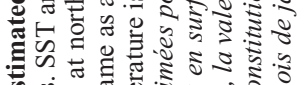

कूष

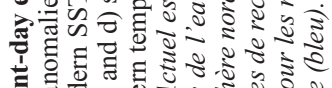

政

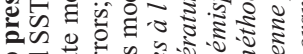

อง

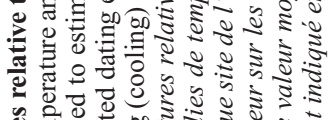

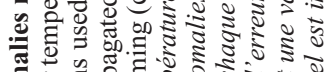



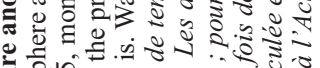

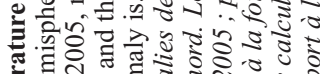

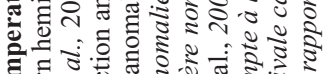

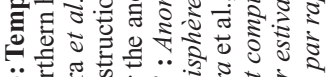

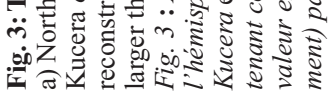


details). We observe warmer-than-present-day climatic conditions at 130,125 , and $120 \mathrm{ka}$ in the southern hemisphere, and at 125 and 120 ka only in the northern hemisphere. Thus, warmer than present-day conditions lasted longer in the southern high latitudes than in the northern ones. The magnitude of temperature changes is also larger in the northern than in the southern high latitudes during the LIG onset and demise (Capron et al., 2014). We take a particular look at the $130 \mathrm{ka}$ time slice. It reveals significantly cooler-than-present-day conditions in the northern high latitudes i.e. on average $5.0 \pm 0.7^{\circ} \mathrm{C}$ cooler), and slightly warmer than present-day conditions in most southern hemisphere sites, i.e. $1.4 \pm 0.4{ }^{\circ} \mathrm{C}$ and $1.7 \pm 0.3{ }^{\circ} \mathrm{C}$ warmer than present-day on average in the Southern Ocean and above Antarctica, respectively. It thus highlights non-synchronous temperature maximum in the two hemispheres. We attribute this interhemispheric asynchrony (e.g. Govin et al., +2012; Capron et al., 2014) to the "bipolar seesaw" mechanism, induced by changes in the intensity of the Atlantic Meridional Overturning Circulation (AMOC; Stocker \& Johnsen 2003). The melting of northern ice sheets extended beyond the penultimate deglaciation into the early LIG, and the associated release of meltwater into the North Atlantic may have delayed the full establishment of a vigorous AMOC, resulting in peak Antarctic temperatures while maintaining cold the North Atlantic (Govin et al., 2012).

Despite its limited spatial extent, this new data synthesis gives so far the sole dynamical representation of LIG high-latitude temperature changes, revealing asynchronous LIG peak temperatures around the globe. In addition, while previous data syntheses (e.g. Turney \& Jones, 2010; McKay et al., 2011) led to limited modeldata comparison outcomes (Otto-Bliesner et al., 2013; Lunt et al., 2013) because they mix the timing of LIG peak warmth in a single time slice (fig. 4a), our new data synthesis provides improved benchmark for climate model snapshot simulations performed across different time intervals of the LIG (e.g. $130 \mathrm{ka}, 125 \mathrm{ka}, 120 \mathrm{ka}$ ), which we illustrate in the next section.

\section{4 - TOWARD IMPROVED LIG MODEL-DATA COMPARISON EXERCISES}

Model-data comparison exercises are useful to help disentangling the forcing and feedbacks shaping the LIG spatio-temporal climate evolution. Here we focus on the time slice at $130 \mathrm{ka}$, and we first compare it with a snapshot simulation performed at $130 \mathrm{ka}$ (see Lunt et al., 2012 for details) with the GCM HadCM3 (Gordon et al., 2000) in the framework of the Paleoclimate Model Intercomparison Project (Phase 3, PMIP3; details on the experimental design of the model simulations can be found in Lunt et al., 2012). Our specific time slice at 130 ka shows that the HadCM3 model reproduces neither the colderthan-present-day North Atlantic conditions nor the early southern hemisphere warming reconstructed at $130 \mathrm{ka}$ (fig. 4b; Capron et al., 2014). This experiment only simulates the climate response to the static orbital and green- house gas forcing at $130 \mathrm{ka}$, and thus, it does not take into account the potential dynamic AMOC response to a persistent melting of northern ice sheets (e.g. Govin $e t$ al., 2012, Sanchez-Goñi et al., 2012), that, we think, is responsible for the bipolar seesaw pattern identified from the data synthesis (section 3). However, other simulations suggest that reproducing the high-latitude climate features at $130 \mathrm{ka}$ is a more complex issue. Indeed, a recent study (Langebroek \& Nisancioglu, 2014) using an alternative GCM shows cooling conditions in the North Atlantic region at $130 \mathrm{ka}$ without the need to invoke a freshwater forcing, while considering a feedback linked to the disintegration of the West Antarctic ice sheet resulted in an additional warming over Antarctica with the HadCM3 model (Holden et al., 2010). These various results call for further investigations.

In order to further examine the role of northern freshwater input on the asynchronous pattern observed at $130 \mathrm{ka}$, we perform sensitivity tests with the HadCM3 model with a freshwater forcing into the North Atlantic of varying intensity (from 0.1 to $1 \mathrm{~Sv}$; see details in Stone et al., 2016). The best fit between model and data results is obtained when using a freshwater forcing of $0.2 \mathrm{~Sv}$, a realistic value considering coral data-based constraints (Carlson, 2008). It is now possible to produce a modelled climate response similar to the colder-than-present North Atlantic temperatures and warmer-than-present Southern Ocean temperatures observed at $130 \mathrm{ka}$ (fig. 4c). Note that it also leads to simulated surface air temperatures over Europe that are consistent with existing continental surface air temperature reconstructions (e.g. Sanchez-Goñi et al., 2012; see fig. 7 from Stone et al., 2016). These new results confirm that the impact of meltwater from the remnant northern ice sheets on global climate via the bipolar seesaw mechanism is a plausible mechanism to explain the early LIG climate as illustrated in the $130 \mathrm{ka}$ time slice. An additional snapshot simulation in which the West Antarctic Ice Sheet is also removed, leads to warming in East Antarctica and the Southern Ocean, although it does not appreciably improve the model-data comparison (fig. 4).

Beyond these results, the time slices and time-series included in our data synthesis have been used to evaluate both LIG transient and snapshot experiments from models of various complexity (Loutre et al., 2014; Pfeiffer \& Lohmann ,2016). It was also recently used as a climate input for ice sheet modelling exercises investigating the contribution of Greenland and Antarctic to LIG sea level changes (DeConto \& Pollard, 2016).

\section{5 - FINAL REMARKS}

In this paper, we summarize three recent and complementary publications on the LIG climate. These new results highlight how the coupling of robust data synthesis with harmonized chronologies and of appropriate climate model experiments significantly improved our spatio-temporal representation of the LIG high-latitude climate evolution, and our understanding of climatic mechanisms that shaped the inter-hemispheric tempera- 
(a)

(b)

(c)

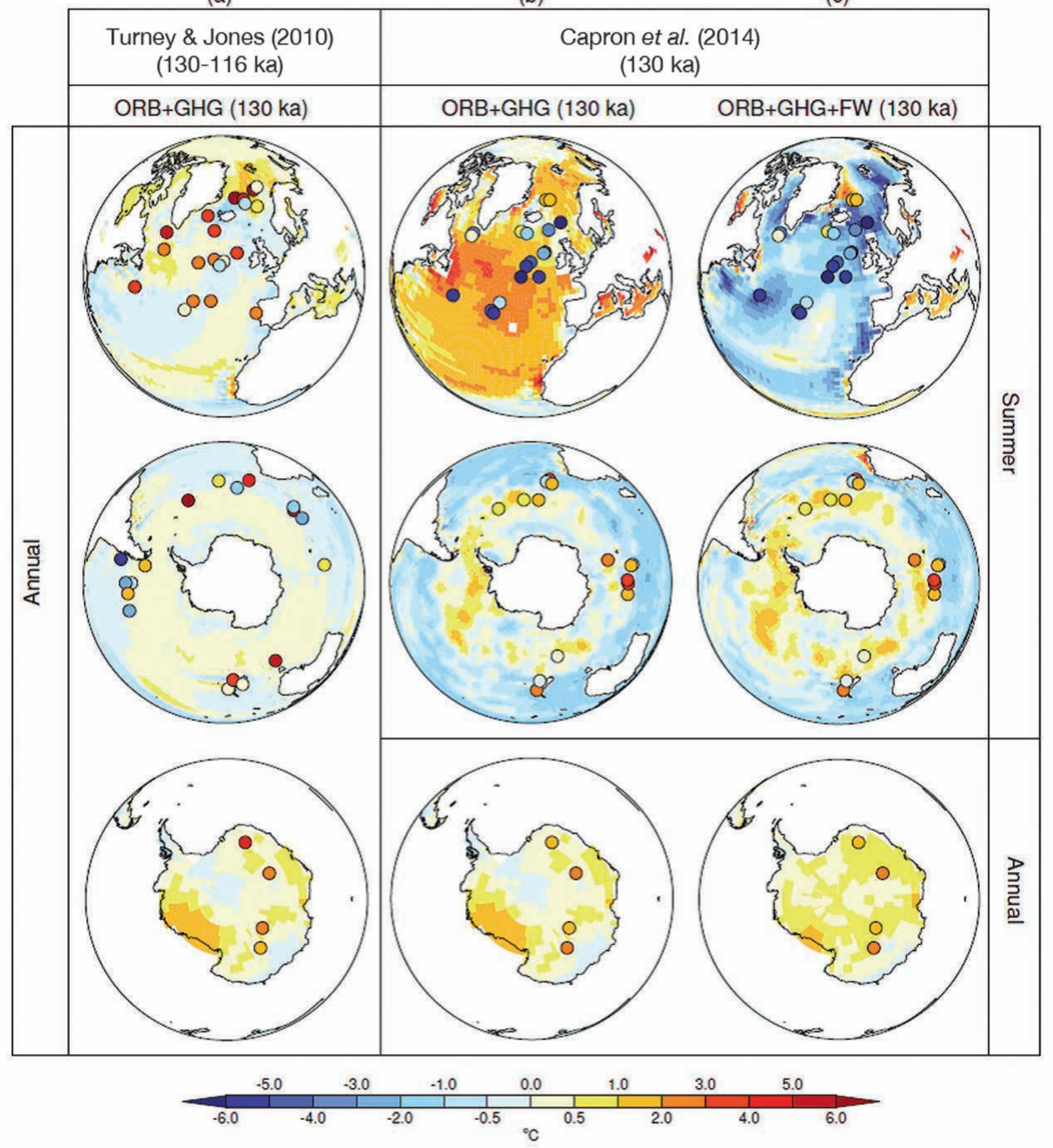

Fig. 4: Comparing 130 ka climate simulations with two LIG data compilation (figure from Stone et al., 2016).

$130 \mathrm{ka}$ SSTs and near surface air temperature anomalies simulated by the HadCM3 model compared with data-based surface temperature time slices for the high-latitude regions. The top two rows are SSTs (annual or summer as labelled) and the bottom row is annual mean near-surface air temperature. Left panel (a): LIG peak warmth data synthesis from Turney and Jones (2010) (dots) superimposed onto the simulated 130 ka annual temperature anomalies (greenhouse gas, GHG, and orbital forcing, ORB, only, Lunt et al., 2013); middle panel (b): the 130 ka data-based surface temperature time slice (dots) superimposed onto simulated summer SST anomalies (for the NH: July, August, and September; for the Southern Hemisphere: January, February and March; greenhouse gas and orbital forcing only, Capron et al., 2014); right panel (c): the 130 ka data-based time slice (dots) compared with summer-SST anomalies for the northern hemisphere and the southern hemisphere (greenhouse gas, orbital forcing, and a constant freshwater input of $0.2 \mathrm{~Sv}, \mathrm{FW}$, into the North Atlantic; Stone et al., 2016). Note the non-linear temperature scale. Anomalies calculated relative to the modern period for both the model and data results.

Fig. 4 : Comparaison entre des simulations climatiques à $130 \mathrm{ka}$ et deux synthèses de données pour le LIG (figure extraite de Stone et al., 2016). Les anomalies de température de l'air et de l'eau en surface issues de reconstitutions paléoclimatiques sont superposées aux anomalies de température de l'air et de l'eau en surface simulées par le modèle HadCM3 pour les régions des hautes latitudes. Les deux panneaux du haut représentent des températures de l'eau de surface (signal annuel ou d'été tel qu'indiqué), le panneau du bas représente des températures de surface annuelles. A gauche (a) : synthèse de données de température de surface de Turney et Jones (2010) centrée sur le maximum de réchauffement (cercles) superposées sur les anomalies de température annuelle simulées à $130 \mathrm{ka}$ (avec HadCM3 forcé seulement par les changements orbitaux, ORB et les changements en gaz à effet de serre, GHG, Lunt et al., 2013) ; au milieu (b) : synthèse de données de température de surface (cercles) superposée aux anomalies de température en été (pour l'hémisphère nord: juillet, aout, septembre ; pour l'hémisphère sud: janvier, février, mars; avec HadCM3 forcé seulement par les changements orbitaux, ORB et les changements en gaz à effet de serre, GHG, Capron et al., 2014) ; à droite (c) : synthèse de données de température de surface (cercles) superposée aux anomalies de température en été (pour l'hémisphère nord : juillet, aout, septembre ; pour l'hémisphère sud : janvier, février, mars; avec HadCM3 forcé par les changements orbitaux, ORB, les changements en gaz à effet de serre, GHG, et un flux d'eau douce constant dans l'Atlantique nord de $0.2 \mathrm{~Sv}, \mathrm{FW}$, Stone et al., 2016). Notez que l'échelle de température n'est pas linéaire. Les anomalies de température sont relatives à l'Actuel à la fois pour les résultats issus des enregistrements paléoclimatiques et ceux simulés par HadCM3. 
ture asynchrony during the LIG. We stress how crucial it is to systematically associate climate alignments used to derive archive's chronologies with (1) a clear statement of the underlying climatic hypothesis, (2) a detailed understanding of environmental parameters controlling selected tracers, (3) a careful evaluation of the synchronicity of aligned paleoclimatic records, and (4) the integration of carefully estimated chronological uncertainties in paleoclimatic investigations.

Our new synthesis with harmonized chronologies provides the first dynamical representation of the LIG climate evolution across the high latitude regions. It illustrates the asynchronous establishment of LIG peak temperature between the two hemispheres, with surface temperatures peaking at $129.3 \pm 0.9 \mathrm{ka}$ in the southern hemisphere, compared to $126.4 \pm 1.9 \mathrm{ka}$ in the North Atlantic and $126.9 \mathrm{ka}$ over Greenland (Capron et al., 2014). The 130 ka time slice provides a very clear illustration of this early LIG climate asynchrony: North Atlantic surface waters were $5.0 \pm 0.7{ }^{\circ} \mathrm{C}$ cooler than present-day, while surface conditions were $1.4 \pm 0.4^{\circ} \mathrm{C}$ and $1.7 \pm 0.3{ }^{\circ} \mathrm{C}$ warmer than present in the Southern Ocean and above Antarctica, respectively. At $125 \mathrm{ka}$, all high-latitude regions experienced warmer-than-present conditions, reaching $1.6 \pm 0.5{ }^{\circ} \mathrm{C}, 0.8 \pm 0.5{ }^{\circ} \mathrm{C}$ and $1.5 \pm 0.2{ }^{\circ} \mathrm{C}$, in the North Atlantic, the Southern Ocean and Antarctica, respectively.

The existence of multiple data-based time slices enables one to evidence important missing processes in state-of-the-art model climate simulations to explain and reproduce the LIG climate evolution. In particular, our integrated model-data approach shows that the input of northern freshwater is an important player in the evolution of the early LIG climate. Our studies also highlight that it is key to compare model simulation with data from the appropriate time period. For this reason, we recently built a $127 \mathrm{ka}$ time slice based on our data synthesis to be used as a benchmark to evaluate the upcoming LIG core simulation at $127 \mathrm{ka}$ that will be performed in the framework of Phase 4 of PMIP (PMIP4) and Phase 6 of the Coupled Model Intercomparison Project (CMIP6) (Capron et al., in revision).

An on-going initiative aims to produce a more comprehensive LIG synthesis of global spatial extent. It will also be associated with a coherent dating, quantitative uncertainty estimates, and it will extend to other parameters than temperature (e.g. stable isotopes) to test the representation of additional climatic tracers in the models included in the CMIP6/PMIP4 exercises.

\section{ACKNOWLEDGMENTS:}

The research leading to these results has received funding from the UK-NERC consortium iGlass (NE/ I009906/1) and is also a contribution to the European Union's Seventh Framework programme (FP7/20072013) under grant agreement 243908, "Past4Future. Climate change - Learning from the past climate". E. C. is funded by the European Union's Seventh Framework
Programme for research and innovation under the Marie Skłodowska-Curie grant agreement no 600207. A.G. has been supported by the Deutsche Forschungsgemeinschaft (DFG) under the special Priority Program INTERDYNAMIC (EndLIG project, grant GO 2122/1-1). This is LSCE contribution number 6010.

\section{REFERENCES:}

BAKKER P. \& RENSSEN H., 2014 - Last Interglacial model-data mismatch of thermal maximum temperatures partially explained. Climite of the Past, 10, 1633-1644.

BAR-MATTHEWS M., AYALON A., GILMOUR M., MATTHEWS A. \& HAWKESWORTH C. J., 2003 - Sea-land oxygen isotopic relationships from planktonic foraminifera and speleothems in the Eastern Mediterranean region and their implication for paleorainfall during interglacial intervals. Geochimica Cosmochimica Acta, 67 (17), 3181-3199.

BAUCH H. A. \& ERLENKEUSER H., 2008 - A "critical" climatic evaluation of last interglacial (MIS 5e) records from the Norwegian Sea. Polar Research, 27 (2), 135-151.

BAZIN L., LANDAIS A., LEMIEUX-DUDON B., TOYÉ MAHAMADOU KELE H., VERES D., PARRENIN F., MARTINERIE P., RITZ C., CAPRON E., LIPENKOV V., LOUTRE M.-F., RAYNAUD D., VINTHER B., SVENSSON A., RASMUSSEN S. O., SEVERI M., BLUNIER T., LEUENBERGER M., FISCHER H., MASSON-DELMOTTE V., CHAPPELlAZ J. \& WOLFF E. W. 2013 - An optimized multi-proxy, multi-site Antarctic ice and gas orbital chronology (AICC2012): 120-800 ka. Climate of the Past, 9, 1715-1731.

BOND G., BROECKER W., JOHNSEN S., MCMANUS J., LABEYRIE L. JOUZEL J. \& BONANI G., 1993 - Correlations between climate records from North Atlantic sediments and Greenland ice. Nature, 365 (6442), 143-147.

CAPRON E., GOVIN A., STONE E. J., MASSON-DELMOTTE V., MULITZA S., OTTO-BLIESNER B., SIME L., WAELBROECK C. \& WOLFF E., 2014 - Temporal and spatial structure of multi-millennial temperature changes at high latitudes during the Last Interglacial. Quaternary Science Reviews, 103, 116-133.

CAPRON E., GOVIN A., FENG R., OTTO-BLIESNER B. \& WOLFF E. W., in revision - A 126-128 ka high-latitude climate time slab to benchmark the Last Interglacial CMIP6/PMIP4 Tier 1 simulation. Quaternary Science Reviews.

CARLSON A. E., 2008 - Why there was not a Younger Dryas-like event during the Penultimate Deglaciation. Quaternary Science Reviews, 27 (9-10), 882-887.

DECONTO R. M. \& POLLARD D., 2016 - Contribution of Antarctica to past and future sea-level rise. Nature, $\mathbf{5 3 1}$ (7596), 591-597.

DRYSDALE R. N., HELLSTROM J. C., ZANCHETTA G., FALLICK A. E., SANCHEZ GONI M. F., COUCHOUD I., MCDONALD J., MAAS R., LOHMANN G. \& ISOLA I., 2009 Evidence for obliquity forcing of glacial termination II. Science, $\mathbf{3 2 5}$ (5947), 1527-1531.

DUTTON A. \& LAMBECK K., 2012 - Ice Volume and Sea Level During the Last Interglacial. Science, 337 (6091), 216-219.

DUTTON A., CARLSON A. E., LONG A. J., MilNe G. A., CLARK P. U., DECONTO R., HORTON B. P., RAHMSTORF S. \& RAYMO M. E., 2015 - Sea-level rise due to polar ice-sheet mass loss during past warm periods. Science, 349 (6244), aaa4019.

GOVIN A., BRACONNOT P., CAPRON E., CORTIJO E., DUPLESSY J.-C., JANSEN E. \& LABEYRIE L., 2012 - Persistent influence of ice sheet melting on high northern latitude climate during the early Last Interglacial. Climate of the Past, 8, 483-507.

GOVIN A., CAPRON E., TZEDAKIS P. C., VERHEYDEN S., GHALEB B., HILLAIRE-MARCEL C., ST-ONGE G., STONER J. S., BASSINOT F., BAZIN L., BLUNIER T., COMBOURIEUNEBOUT N., EL OUAHABI A., GENTY D., GERSONDE R., JIMENEZ-AMAT P., LANDAIS A., MARTRAT B., MASSONDELMOTTE V., PARRENIN F., SEIDENKRANTZ M.-S., VERES D., WAELBROECK C. \& ZAHN R., 2015 - Sequence of events from the onset to the demise of the Last Interglacial: Evaluating strengths and limitations of chronologies used in climatic archives. Quaternary Science Reviews, 129, 1-36. 
HOLDEN P. B., EDWARDS N. R., WOLFF E. W., LANG N. J., SINGARAYER J. S., VALDES P. J. \& STOCKER T. F., 2010 Interhemispheric coupling, the West Antarctic Ice Sheet and warm Antarctic interglacials. Climate of the Past, 6, 431-443.

KUCERA M., ROSELL-MELÉ A., SCHNEIDER R., WAELBROECK C. \& WEINELT M., 2005 - Multiproxy approach for the reconstruction of the glacial ocean surface (MARGO). Quaternary Science Reviews, 24 (7-9), 813-819.

LANGEBROEK P. M. \& NISANCIOGLU K. H., 2014 - Simulating last interglacial climate with NorESM: role of insolation and greenhouse gases in the timing of peak warmth. Climate of the Past, 10, 1305-1318.

LISIECKI L. E. \& RAYMO M. E., 2005 - Plio-Pleistocene Stack of 57 Globally Distributed Benthic $\mathrm{d}^{18} \mathrm{O}$ Records. Paleoceanography, 20, PA1003.

LOULERGUE L., SCHILT A., SPAHNI R., MASSONDELMOTTE V., BLUNIER T., LEMIEUX B., BARNOLA J. M., RAYNAUD D., STOCKER T. F, \& CHAPPELLAZ J., 2008 - Orbital and millennial-scale features of atmospheric $\mathrm{CH}_{4}$ over the past 800,000 years. Nature, $\mathbf{4 5 3}$ (7193), 383-386.

LOUTRE M. F., FICHEFET T., GOOSSE H., HUYBRECHTS P., GOELZER H. \& CAPRON E., 2014 - Factors controlling the last interglacial climate as simulated by LOVECLIM1.3. Climate of the Past, 10, 1541-1565.

LUNT D. J., A. ABE-OUCHI A., BAKKER P., BERGER A., BRACONNOT P., CHARBIT S., FISCHER N., HEROLD N., JUNGCLAUS J. H., KHON V. C., KREBS-KANZOW U., LANGEBROEK P. M., LOHMANN G., NISANCIOGLU K. H., OTTO-BLIESNER B. L., PARK W., PFEIFFER M., PHIPPS S. J., PRANGE M., RACHMAYANI R., RENSSEN H., ROSENBLOOM N., SCHNEIDER B., STONE E. J., TAKAHASHI E., WEI W., YIN Q. \& ZANG Z. S., 2013 - A multi-model assessment of last interglacial temperatures. Climate of the Past, 9, 699-717.

LÜTHI D., LE FLOCH M., BEREITER B., BLUNIER T., BARNOLA J.-M., SIEGENTHALER U., RAYNAUD D., JOUZEL J., FISCHER H., kaWAMURA K. \& STOCKER T. F., 2008 - High-resolution carbon dioxide concentration record 650,000-800,000 years before present. Nature, $\mathbf{4 5 3}$ (7193), 379-382.

MASSON-DELMOTTE V., BRACONNOT P., HOFFMANN G., JOUZEL J., KAGEYAMA M., LANDAIS A., LEJEUNE Q., RISI C., SIME L., SJOLTE J., SWINGEDOUW D. \& VINTHER B. 2011 - Sensitivity of interglacial Greenland temperature and $\mathrm{d}^{18} \mathrm{O}$ : ice core data, orbital and increased $\mathrm{CO}_{2}$ climate simulations. Climate of the Past, 7, 1041-1059.

MASSON-DELMOTTE V., SCHULZ M., ABE-OUCHI A., BEER J., GANOPOLSKI A., GONZALEZ ROUCO J. F., JANSEN E., LAMBECK K., LUTERBACHER J., NAISH T., OSBORN T., OTTO-BLIESNER B., QUINN T., RAMESH R., ROJAS M., SHAO X. \& TIMMERMANN A., 2013 - Information from paleoclimate archives. In Stocker, T.F., Qin, D., Plattner, G.-K., Tignor, M., Allen, S.K., Boschung, J., Nauels, A., Xia, Y., Bex, V., Midgley, P.M. (eds.), Climate Change 2013: the Physical Science Basis. Contribution of Working Group I to the Fifth Assessment Report of the Intergovernmental Panel on Climate Change. Cambridge University Press, Cambridge, United Kingdom and New York, NY, USA, 383-464.

MCKAY N. P., OVERPECK J. T. \& OTTO-BLIESNER B. L., 2011 - The role of ocean thermal expansion in Last Interglacial sea level rise. Geophysical Research Letters, 38, L14605.
NEEM COMMUNITY MEMBERS 2013 - Eemian interglacial reconstructed from a Greenland folded ice core. Nature, 493 (7433), 489-493.

NORTHGRIP COMMUNITY MEMBERS 2004 - High-resolution record of Northern Hemisphere climate extending into the last interglacial period. Nature, 431 (7005), 147-151.

OTTO-BLIESNER B., ROSENBLOOM N., STONE E., MCKAY N. P., LUNT D. J., BRADY E. C. \& OVERPECK J. T., 2013 How warm was the Last Interglacial? New model-data comparisons. Philosophical Transactions of the Royal Society A: Mathematical. Physical \& Engineering Sciences, 371, 20130097.

PFEIFFER M. \& LOHMANN G., 2016 - Greenland Ice Sheet influence on Last Interglacial climate: global sensitivity studies performed with an atmosphere-ocean general circulation model. Climate of the Past, 12,1313-1338.

SÁNCHEZ-GOÑI M. F., BAKKER P., DESPRAT S., CARLSON A. E., VAN MEERBEEK C. J., PEYRON O., NAUGHTON F., FLETCHER W. J., EYNAUD F., ROSSIGNOL L. \& RENSSEN H., 2012 - European climate optimum and enhanced Greenland melt during the Last Interglacial. Geology, 40, 627-630.

SHACKLETON N. J., HALL M. A. \& VINCENT E, 2000 - Phase relationships between millennial-scale events $64,000-24,000$ years ago. Paleoceanography, 15 (6), 565-569.

SHACKLETON N. J., SÁNCHEZ-GOÑI M. F., PAILLER D. \& LANCELOT Y., 2003 - Marine Isotope Substage 5e and the Eemian Interglacial. Global and Planetary Change, 36 (3), 151-155.

SKINNER L. C. \& SHACKLETON N. J., 2005 - An Atlantic lead over Pacific deep-water change across Termination I: implications for the application of the marine isotope stage stratigraphy. Quaternary Science Reviews, 24 (5-6), 571-580.

SKINNER L. C. \& SHACKLETON N. J., 2006 - Deconstructing Terminations I and II: revisiting the glacioeustatic paradigm based on deep-water temperature estimates. Quaternary Science Reviews, 25 (23-24), 3312-3321.

STOCKER T. F. \& JOHNSEN S. J., 2003 - A minimum thermodynamic model for the bipolar seesaw. Paleoceanography, 18, 1087.

STONE E. J., CAPRON E., LUNT D. J., PAYNE A. J., SINGARAYER J. S., VALDES P. J. \& WOLFF E. W., 2016 - Impact of melt water on high latitude early Last Interglacial climate. Climate of the Past, 12, 1919-1932.

TURNEY C. S. M. \& JONES R. T., 2010 - Does the Agulhas Current amplify global temperatures during super-interglacials? Journal of Quaternary Science, 25 (6), 839-843.

VERES D., BAZIN L., LANDAIS A., TOYÉ MAHAMADOU KELE H., LEMIEUX-DUDON B., PARRENIN F., MARTINERIE P., BLAYO E., BLUNIER T., CAPRON E., CHAPPELLAZ J., RASMUSSEN S. O., SEVERI M., SVENSSON A., VINTHER B. \& WOLFF E. W., 2013 - The Antarctic ice core chronology (AICC2012): an optimized multi-parameter and multi-site dating approach for the last 120 thousand years. Climate of the Past, 9, 1733-1748.

WAELBROECK C., SKINNER L. C., LABEYRIE L., DUPLESSY J.-C., MICHEL E., VAZQUEZ RIVEIROS N., GHERARDI J.-M. \& GHERARDI F. D., 2011 - The timing of deglacial circulation changes in the Atlantic. Paleoceanography, 26, PA3213. 